\title{
Learning through projects: identifying opportunities for individual professional learning and development
}

Claire Dickerson*, Joy Jarvis and Roger Levy

School of Education, University of Hertfordshire, Hatfield, UK

* Corresponding author:

Email: j.e.c.dickerson@herts.ac.uk

Author accepted manuscript. The Version of Record of this manuscript has been published and is available in Professional Development in Education published online 24 May 2013 http://www.tandfonline.com/doi/abs/10.1080/19415257.2013.794747. 


\begin{abstract}
This article is based on findings from the evaluation of a project established to enhance learning and teaching in higher education. This project took place within the University of Hertfordshire School of Education in England through the Change Academy for Blended Learning Enhancement (CABLE) project, the University version of the UK Higher Education Academy and Joint Information Systems Committee Pathfinder programme. The purpose of the project within the School was to increase the support for students' reading at Master's degree level. The evaluation approach for the project was based on RUFDATA, which provides a framework for evaluation activity. Stakeholders' reflections on the process and outcomes of the project included the contribution it had made to teaching and learning, and the opportunities it had provided for personal and professional learning and development. The CABLE project is one example of the many funded projects that are a common feature in higher education settings; all potentially of value for individual, team and organisational learning. In this article, the findings from the evaluation are used to suggest some questions that might be asked in future projects to prospectively and proactively identify opportunities for individual professional learning and development.
\end{abstract}

Keywords:

CABLE project; evaluation; learning from projects; organisational learning; professional development; professional learning 


\section{Introduction}

This article is based on findings from the evaluation of a project established to enhance learning and teaching in higher education. The focus of the project within the University of Hertfordshire School of Education was to increase the support for academic reading at Master's degree level by using blended learning. The purpose of this article is to present and discuss some of the evaluation findings arising from a survey of project team members and to use the findings to demonstrate ways in which projects might provide opportunities for individual professional learning and development. This is an essential component of the progression towards organisational learning (Argyris and Schön, 1978). A report of those aspects of the project relevant to student involvement has been published elsewhere (Levy et al, 2011).

The next section of the article outlines the potential value of projects in relation to individual, team and organisational learning and identifies some of the issues of these types of learning. The article then describes the project itself and the way in which it was carried out and evaluated before presenting and discussing some of the evaluation findings. The findings from the evaluation of the project are used to suggest some questions that might be asked in future projects to proactively identify opportunities for professional learning and development.

\section{Background}

\section{Individual, team and organisational learning}

Following a review of the literature on organisational learning, Argyris (1999, p. 1) divided it into the 'scholarly literature of "organizational learning"' put forward by academics; and the practice-focused literature of 'the learning organization' proposed mainly by practitioners and consultants. Said by Senge (2006, p. 14) to mean 'an organization that is continually expanding its capacity to create its future', Fullan (1993) suggests that learning organisations are necessary because change in complex systems is chaotic and non-linear.

The debates Argyris identified as a result of the literature review focused on the issue of 'productive organizational learning' (Argyris, 1999, p. 19). He raised the question of the level of aggregation (ranging through a series of stages from individual to whole organisation) at which it is sensible to talk of productive organisational learning; the meaning of and barriers to this type of learning; and ways of enhancing the capability of organisations for productive learning. In discussing the meaning of productive organisational learning, Argyris distinguished between single-loop learning and two types of organisational double-loop learning. Referring to the work of Argyris, Bloch and Borges (2002, p. 464) note 'that overcoming personal and organisational barriers and acquiring new behavioural skills are very lengthy processes'.

Organisational learning involves individuals, groups or teams of individuals, and the organisation as a whole in a continual process of assessing and sharing experience (Barker and Neailey, 1999). Whilst recognising the importance of individual learning as the starting point of organisational learning, these authors note that this in itself is not sufficient and emphasise the role of learning within teams. Other authors also acknowledge the importance 
of the individual learner as the basis for organisational learning (for example, Argyris and Schön, 1978; Mumford, 1991; Ayas, 1996). Mumford (1991, p. 115), for example, suggests that:

'Change is a function of the interaction between an individual and an organisation. Current concepts about organisational learning are stronger on concepts than on practical processes. These processes must be built on the individual learner first. Learning to learn then leads to continuous learning, and a full understanding of learning (especially at work) as a sequential process not a series of separate events.'

Whilst acknowledging that individual learning is a necessary feature, Argyris and Schön (1978) also point out that this is not in itself a sufficient condition for organisational learning. Drawing on Argyris and Schön's levels of double-loop and deutero learning in relation to organisational learning, Fischer and Röben (2002, p. 2-3) suggest that:

'Organisational learning in the sense of double-loop and deutero learning implies that the organisation has created a structure through which individual learning is permanently stimulated, documented and evaluated. It is this organisational structure by which organisational learning is differentiated from pure individual learning. In other words: organisational learning changes the structures and not only the people...

'Such a structure is only put into practice, however, if organisational learning is not only a formal demand but a cultural phenomenon...'

Senge (2006, p. 10) however, stresses the importance of team learning, suggesting that teams rather than individuals 'are the fundamental learning unit in modern organizations', thus representing a move to a larger unit. Working in teams can provide great opportunities for learning, and collective reflection on experience allows team members to build on the ideas of others and enhance their thinking and understanding (McDermott, 1999). Using the idea of 'the "double-knit" organization', McDermott (1999, p. 36) suggests that: 'Rather than sharing learning from one whole team to another, a double-knit organization links individual team members with people from other teams in networks and [Communities of Practice].'

Differences between organisational learning environments and the degree to which they might be able to improve the quality of the learning environment can be analysed using the expansive-restrictive continuum, a conceptual framework devised by Evans et al (2006).

\section{Projects as a source of individual, team and organisational learning}

Keegan and Turner (2001, p. 77) note that although projects are commonly seen as an essential means of achieving change, 'project-based learning practices - as a subset of organizational learning practices - have not kept pace with this development'. Based on their assumption that project-based learning is an important potential source of organisational learning, they draw on their findings from a study of the project learning practices of nineteen firms to suggest some factors that can impede organisational learning. The barriers they cite 'include lack of time and reflection at the level of the project team, the tendency to centralize learning and the deferral of learning to future points in time and space' (Keegan and Turner, 2001, p. 83). Project learning can focus on activities within a single project (intra-project learning) or between projects (inter-project learning) when lessons learned are shared across projects to use and develop new knowledge (Kotnour, 2000). 
A learning organisation may need the action orientation associated with projects, but dialogue is also key in this process (Mazutis and Slawinski, 2008). Dialogue may be seen as a relatively straightforward process of sharing learning, but an increasing number see this as a complex, iterative process, in which learning is partial and continually developed (Oswick et al, 2000) through adaptive interactions (Stacey, 2001).

Project-based learning arises in project teams and the end of a project often marks 'the end of collective learning' (Schindler and Eppler, 2003, p. 220). Team members frequently start new projects before they have had time to capture the learning from the one they have just completed (Keegan and Turner, 2001). Although thorough documentation of a project can provide an opportunity to reflect on activities, learn lessons for future planning and practice, and facilitate sharing, resources are rarely available to capture experiences and knowledge in this way (Chavez-Tafur et al, 2007).

Several approaches have been developed to support learning from projects and to contribute to organisational learning or can be adapted to meet those requirements. Table 1 provides the title, brief description and timing of six of these approaches. Some of these are designed to be used to identify learning at the end of a project, although such deferral can adversely effect reflective learning throughout the project (Keegan and Turner, 2001). Additional practical tools that are used to support learning in organisations include action learning sets, advice network mapping, case study development, exchange programmes, exit interviews, The 'Learning Before, During and After (LBDA) Model', learning maps and yellow pages (Britton, 2002).

Table 1 Title, description and timing of approaches available to support learning from projects

\begin{tabular}{|l|l|}
\hline Title & Brief description and timing \\
\hline $\begin{array}{l}\text { 1) After action review } \\
\text { Schindler and Eppler, 2003; } \\
\text { NHS National Library for } \\
\text { Health: Specialist Library } \\
\text { Knowledge Management, } \\
\text { 2005) }\end{array}$ & $\begin{array}{l}\text { An action orientated process with team learning and integrity, and } \\
\text { building trust as goals of the review. After action reviews can be } \\
\text { used to make tacit learning explicit during a project and allow it to } \\
\text { be recorded and shared. } \\
\text { Timing: After an identifiable activity (for example, during a project) } \\
\text { or post-project }\end{array}$ \\
\hline $\begin{array}{l}\text { 2) Individual/ team learning } \\
\text { methodology } \\
\text { (Barker and Neailey, 1999, p. }\end{array}$ & $\begin{array}{l}\text { 'a methodology for capturing team learning that brings together the } \\
\text { contribution of individuals into a team context while maintaining a } \\
\text { focus throughout the process on the need for innovative change.' } \\
\text { Timing: Post-project }\end{array}$ \\
\hline $\begin{array}{l}\text { 3) Learning from experience } \\
\text { (Chavez-Tafur et al, 2007) }\end{array}$ & $\begin{array}{l}\text { A field based documentation method, in which the term } \\
\text { 'documentation' is used to mean a process which seeks to organise } \\
\text { information arising from a specific project so that it can be analysed } \\
\text { in detail and lessons can be drawn from it. The main objective is to } \\
\text { generate new knowledge. } \\
\text { Timing: Post-project but much of the information could be collated } \\
\text { during a project. }\end{array}$ \\
\hline $\begin{array}{l}\text { 4) Learning histories } \\
\text { (Roth and Kleiner, 1998, p. 47) }\end{array}$ & $\begin{array}{l}\text { A process 'for developing organizational memory that builds on an } \\
\text { organization's actual learning and transformation experiences.' }\end{array}$ \\
\hline
\end{tabular}




\begin{tabular}{|l|l|}
\hline Title & Brief description and timing \\
\hline & Timing: Usually post change process/activity/project \\
\hline $\begin{array}{l}\text { 5) The 'Most Significant } \\
\text { Change' (MSC) Technique } \\
\text { (Davies and Dart, 2005, p. 13) }\end{array}$ & $\begin{array}{l}\text { A form of participatory monitoring and evaluation. In the } \\
\text { experience of the authors, 'MSC is suited to monitoring that focuses } \\
\text { on learning rather than just accountability. It is also an appropriate } \\
\text { tool when you are interested in the effect of the intervention on } \\
\text { people's lives and keen to include the words of non-professionals.' } \\
\text { Timing: Can be used throughout the project cycle }\end{array}$ \\
\hline $\begin{array}{l}\text { 6) Project reflection } \\
\text { workshop } \\
\text { (Church Urban Fund, 2006) }\end{array}$ & $\begin{array}{l}\text { The aim of this project evaluation and assessment tool is to create } \\
\text { greater ownership of the decision-making process for project } \\
\text { stakeholders by organising a process of reflection and providing the } \\
\text { opportunity to share learning. } \\
\text { Timing: Depending on the scale of the project this could be used at } \\
\text { different stages (or for part of a project) or just at the end. }\end{array}$ \\
\hline
\end{tabular}

\section{Change Academy for Blended Learning Enhancement (CABLE) project}

The UK Higher Education Academy (HEA) and Joint Information Systems Committee (JISC) Pathfinder Programme emphasised the planning, implementation and evaluation of different approaches intended to embed technology-enhanced learning in ways that lead to positive organisational change (Mayes et al, 2008). Part of the Higher Education Funding Council for England's ten year e-learning strategy, the programme supported the development of the organisational and pedagogical contexts and processes which are necessary for technology to be used to achieve positive learning outcomes. The HEA is the national organisation for learning and teaching within the UK and JISC (now known as Jisc) is a registered charity that works on behalf of UK higher education, further education and skills to support the use of digital technologies.

The University of Hertfordshire version of the Pathfinder Programme called Change Academy for Blended Learning Enhancement (CABLE) was developed 'to bring about significant curricular and structural change at the University of Hertfordshire, specifically to embed blended learning within the Academic Schools' (Anderson et al, 2008, p. 30). The HEA Change Academy is a programme of support for team-based learning and professional development that facilitates complex change in higher education institutions (Higher Education Academy, 2011). Within the University, the CABLE process was managed by a Steering Group, which included members of the Blended Learning Unit, the People Development Unit, Learning and Information Services and an external advisor. The School of Education was one of six Academic Schools to take part in the programme.

Within the School, the purpose of the project was to increase the support for reading at Master's degree level by using blended learning. The Managing Professional Development module from the Education Continuing Professional Development (CPD) programme was chosen as the focus for the project. This programme had approximately 150 part-time students studying at Master's level and employed in a range of professional workplace contexts.

The project team within the School, led by a senior member of staff, included a student representative from the module and eight members of staff with expertise in, and 
responsibility for, strategic and operational developments in learning and teaching within the School. Team members were supported by two colleagues from the Blended Learning Unit.

Early in the project life cycle, the team leader met with the University project co-ordinator and project team leaders from the other Academic Schools. These meetings were followed by School team meetings and a residential event for members of each of the project teams, members of the Blended Learning Unit, facilitators, students and a representative of the HEA. The event activities included the development of project plans, action plans, spending plans and evaluation strategies; identification of staff development needs; and assessment of preferred Belbin team roles.

Previously cited in Anderson et al (2008, p. 35), the main objectives of the event were to:

- Provide an opportunity to share plans with other teams in order to gain constructive feedback and identify opportunities for working together;

- Continue the development of the team;

- Continue staff development and identify further development needs;

- Continue to develop partnerships between the Blended Learning Unit and Schools;

- Provide a range of opportunities and support to ensure factors that would enhance the likelihood of success of the project had been properly considered;

- Finalise team project objectives and produce a robust action plan that included an evaluation strategy.

The HEA work package template was used for action planning. This template provided a framework for documenting the start and completion dates, outputs, budgeted cost and responsibility for each of the work package activities. Within the School, five work packages were identified early in the project process; three of these related to providing additional support for students' reading and the remaining two focused on communication and dissemination of project outcomes and on developing and implementing the evaluation strategy. Outputs from the first three work packages were trialled in the Managing Professional Development module.

Within the School, the process of project development was characterised by a series of scheduled informal and formal team meetings, and ad hoc 'corridor meetings'. Informal meetings were held approximately fortnightly to allow the team members to get together to discuss progress and other issues. More formal meetings also continued throughout the project to allow updating of each work package with a summary of progress and identification of specific next steps and goals. Individual team members were encouraged to reflect on the project by preparing visual representations of their first thoughts (feelings/perceptions etc.) on joining the team and the experience of the residential event.

Students and staff within the School were involved throughout the project. For example, staff were invited to respond to corridor posters used to disseminate the project and also contributed to a School-based professional development session. Team members presented at a University Showcase and Conference. The student team member contributed to dissemination activities and reflection and together with her colleagues provided feedback and evaluation of project outputs.

Towards the end of the project, some team members attended a one-day meeting, which included a presentation from each of the six Academic School project teams. The purpose of 
the presentations was to allow reflection on the challenges and achievements so far and identify future plans; to produce a resource to support dissemination and evaluation; to provide an opportunity for finding synergies or ideas for the project; and to share reflections on the CABLE process.

\section{Evaluation method}

The evaluation approach for the project was based on RUFDATA (Saunders, 2000), an acronym which provides the following framework for evaluation activity: reasons and purposes, uses, focus, data and evidence, audience, timing and agency. The evaluation was planned from the beginning of the project.

The purpose of the evaluation was to establish the extent to which the aim of the project had been achieved and how it had been achieved. It was designed to inform the development of the support for students' reading in other areas of the School and to increase understanding of change management within the School. The evaluation focused on the process and outcomes of the first ten months of the project. It was conducted by a research fellow within the School, in collaboration with members of the School of Education project team.

The evaluation activities were designed in consultation with members of the project team and were also informed by desk-based research.

Data were collected through:

- A review of project documents. These included electronic and paper-based resources, for example, weblogs, meeting reports and presentations.

- A survey of stakeholders. Stakeholders were invited to contribute their reflections of aspects of the project by engaging in a face-to-face interview or completing a questionnaire distributed via email. The questions were the same for both methods of administration.

- A survey of module participants. Students on the Master's level Managing Professional Development module were invited to complete module evaluation forms at the beginning and end of the module.

- Attendance at project meetings. Information relevant to the evaluation was noted at scheduled and informal team meetings, including a professional development session.

The evaluation was covered by the University Protocol for Reflective Practitioner Work by Academic Staff. Individual participants cannot be identified from the published data.

\section{Evaluation findings}

Findings from the stakeholder survey are presented in this article. Feedback on the student involvement in the project team is published in detail elsewhere together with the results of the survey of module participants (Levy et al, 2011). 


\section{Reflection on the process of the CABLE project}

Eight project stakeholders took part in the survey. The participants included one member of the Steering Group; two members of staff with a strategic view of the project within the School of Education (one acting as a 'critical friend') and five members of the project team within the School, including the student representative and the team leader. Some of their reflections on the strategic implications of the project, practical issues, quality issues and future developments are provided here.

\section{Strategic implications of the project}

One respondent identified two strands in relation to the implications of the project for the School of Education strategic plan. The first strand was the process, change management approach, a more formalised way of working, which would be used for other initiatives and activities. The second strand was the Master's level reading, which would also have implications for other work.

In relation to the strategic implications of the project, a second respondent suggested:

'I'm not sure that we have addressed this enough as yet. We have been focussed on what CABLE can do in terms of the School of Education's teaching and learning but perhaps we need to think more carefully about its direction to the overall strategic direction of the School of Education.'

One member of the project team recommended using a proactive approach to supporting staff to develop skills and confidence in using blended learning. For example, by allocating members of staff time with a blended learning specialist as part of induction and mentoring and follow up.

Several respondents were able to identify implications of the project for the partnership between the School of Education and the Blended Learning Unit. A stronger link with the Blended Learning Unit was identified as one of the impacts of the project within the School. Two respondents commented on the link as follows:

'I think it has helped us to make professional relationships which were not there to the same extent before. We have come to understand them more and hopefully they understand more about what we are doing.'

'Now they know us and we know them...increased communication in the future will build on this mutual trust and respect for deeper understanding and further collaborative strategic work...'

\section{Practical issues}

Several aspects of the planning and implementation of the project were identified as 'most useful' in response to questions relating to practical issues. These included:

- the residential event arranged at the beginning of the project for members of the Blended Learning Unit, the six project teams, facilitators, students and an HEA representative; 
- the discussions (not necessarily in formal meetings);

- team working and learning more about colleagues;

- opportunities for networking;

- the availability of the Blended Learning Unit team;

- the opportunity to learn more ICT skills and discovering the range of resources available.

For example, one respondent commented:

'The residential was really good - because we were away - able to really focus and talk through issues as we perceived it. Another thing that helped the process was having a member of staff with designated time to do the work.'

A second respondent made several suggestions, which included:

'The opportunity to work with an excellent group of colleagues on an identified issue. Some time and space.'

'Making links with others in the University - ie Learning and Information Services and their project...Having a [seminar] which allowed a range of people to hear about the ideas and to contribute their own. Having time with small groups of colleagues to work on the project.

Learning more about colleagues and how they teach and think...Working with people I might not have had the chance to work with otherwise. Seeing more clearly the potential for the use of ICT in learning and teaching.'

Those aspects of the planning and implementation of the project respondents found 'least useful' included using the Belbin team analysis; carrying out a risk analysis; and the timescale for the project. The way in which the project was broken down into sub-projects (work packages) was seen as a useful framework by one respondent, but not by another. Similarly, the project website was put forward as an example of good practice by one respondent but a second colleague reported that they did not find it useful.

When asked about the impact they felt the project had made on them, one respondent commented:

'Really interesting to look beyond the School of Education and mix with people from other Schools and Faculties. Find out about other styles and organisation, for example, the way power is devolved and delegated...'

Participants also highlighted the following issues in response to this question:

- good staff development; useful as a personal development project;

- greater understanding of team development;

- greater focus on listening to the student voice in relation to learning and teaching;

- greater awareness of the range of resources available to support reading and of the importance of supporting students' reading and writing development;

- greater awareness of what others understand about blended learning and their level of skills, awareness and attitude to blended learning;

- greater confidence about linking with the Blended Learning Unit and more aware of what they could offer the School;

- greater awareness of the potential of the use of ICT in learning and teaching;

- greater confidence in the use of some ICT. 
In terms of the impact of the project on the learning experience with students most respondents felt it was too early in the project to answer this question.

\section{Quality issues and future developments}

Most of the main benefits of the project suggested by respondents can be grouped within the following themes:

- contribution to teaching and learning, including focussing on reading and sharing ideas on this aspect of learning and teaching; and developed reading skills;

- $\quad$ project deliverables and resources;

- raised profile of blended learning within the School;

- links with the Blended Learning Unit;

- increased networking opportunities (within the School and outside);

- closer working with professional staff (technicians);

- aspirational team working;

- personal development of staff (including upskilling and increased confidence);

- raised profile of the School of Education.

In terms of professional development opportunities one respondent commented:

'The project's provided a receptacle for existing 'good practice' in teaching and learning drawing on the blended learning good practice. The huge benefit is the upskilling of a large number of members of staff - even those not particularly in the project have got swept along with some of the emergent findings.'

Respondents identified many examples of good practice. These included the team meetings and their frequency; team building and small group work; excellent leadership; involving others in the project (for example, a student, a technician, and critical friends); communication and the use of posters for dissemination within the School; care for the student voice; and the development of good resources.

Time and time-scale were the main constraints or limitations of the project most noted by respondents. Other suggestions included: members being away, communication constraints, using Belbin team analysis; and the need for a physical project space and specific resources to disseminate the ongoing work.

Some of the issues raised in response to earlier questions were seen as 'lessons learnt' from the project. Once again, the question of timing and the time-scale was raised. Other lessons learnt related to the importance of team working and project leadership and management; the importance of listening to students' voices; the value of University-wide networking opportunities and the celebration of achievement. The guidance that came from the structure of the Pathfinder Programme and the support of the Blended Learning Unit team were commended. 
One respondent identified the following opportunities for professional development:

'...That it would be a good idea to identify how we work together effectively so that we can use our skills in the best way. That it would be a good idea to develop more project leaders use people who are good at this to support and mentor others rather than lead projects themselves? That working in teams on small projects is a good form of staff development and of developing areas within the School of Education. That links with other people and groups across the University are helpful...'

One final comment summed up the project as follows:

'It was a good learning experience.'

\section{Discussion}

\section{Learning from the CABLE project}

The project had a clearly defined purpose or goal for change (Denton, 1996); to enhance the support for students' reading at Master's level using blended learning. The whole process within the School of Education was characterised by regular team meetings, sustained professional dialogue, reflection, and listening to the ideas of students and members of staff. The evaluation process provided an opportunity for project stakeholders to reflect on some of the learning from the project. Participants reported that the project had made an impact on the School in several ways. For example, it had provided further opportunities for learning about the change process, closer links with the Blended Learning Unit and more opportunities for networking. Informal professional learning experiences such as networking can be particularly valuable, a finding reported by Bickmore (2011) following a survey of school administrators carried out within the United States. This issue was also highlighted in the report of the Benchmarking and Pathfinder programmes, in which the authors note that the phrase 'building relationships' could be used to sum up the main outcome (Mayes et al, 2008, p. 4). Many of the features identified by the participants within the School of Education were not confined to the core project team; one colleague noted the benefit of the project in terms of members of staff not particularly involved in the project.

Although the project was constrained by the timing and the time-scale, the many positive reflections included the project management and aspirational team working; the contribution it had made to teaching and learning; and the opportunities it had provided for personal and professional learning and development. Mitchell et al (2010, p. 536) use the term 'professional learning', in the school context, to describe formal opportunities for learning and 'more informal processes of teachers' learning associated with thinking about and reflecting on aspects of their practice', both of which might be associated with the project setting. This potential for learning, which tends to be overlooked in the traditional perspective of projects and project teams simply as distinct, time limited activities that focus on specific outcomes, can be used to re-characterise projects to move 'on-the-job learning and the socio-cultural conditions that nurture it...towards the forefront of project activities' (Sense, 2009, p. 195). A review of the CABLE project process and evaluation findings suggests that, in common with many projects, it had met most of the following characteristics or activities through which people learn, namely: participation in group activities, working alongside others, tackling 
challenging tasks, and working with clients (Eraut, 2004). The ongoing collaboration with colleagues that can arise through participation in a project team can impact directly on professional practice (Lom and Sullenger, 2011).

When the aims of a project are not too tightly defined there is room for adaptive interaction, involving reflection and reflexivity, through which deep learning can take place (Stacey, 2001). There is also the potential to make the tacit learning that takes place in projects become explicit, thus increasing the potential for deep learning to develop. Ayas (1996, p. 131), during a discussion of 'professional project management', highlights the complexity of learning within projects, suggesting that this process 'needs to be managed. It requires commitment and continuous investment of resources.' Keegan and Turner (2001, p. 94) also recognised that creating the space for learning has resource implications, noting that:

'Insufficient resources are dedicated to helping project teams to consistently view projects as learning opportunities, and to use feedback mechanisms to capture learning experiences and share them within the team and over time with the organization.'

There is also an opportunity to use resources to support the process of making tacit learning explicit, thus encouraging the development of organisational learning, particularly if this explicit learning can then be internalised and become tacit (Nonaka and Takeuchi, 1995). The suggestion here is that projects can be constructed as one of the ways in which a professional environment can be 'expansive' rather than 'restrictive' (Evans et al., 2006) in promoting opportunities for learning alongside the necessary task completion, aligning with Eraut's (2004) emphasis on the importance of learning within informal situations.

Argote and Miron-Spektor (2011) view the creation, retention and transfer of knowledge as three sub processes of organisational learning processes. Although this knowledge can include both explicit and tacit components, Boreham et al. (2002) have suggested that much of the knowledge in organisations is tacit, and embedded in social relations in the workplace.

Making such 'knowledge based on the experience of individuals' explicit can be challenging, although sharing can be reinforced in situations that allow face-to-face interaction, for example, through dialogue, and can be influenced by other factors such as the language used, trust and co-location (Koskinen et al, 2003, p. 281). Fong (2003) also stressed the importance of interpersonal communication for the effective transfer of tacit knowledge. In the project setting, team working can facilitate the creation of common or group tacit knowledge by converting the tacit knowledge of individuals, the basis of organisational knowledge, into the tacit knowledge of the group through interacting and sharing experiences ('socialization') (Nonaka et al, 1996, p. 205), and team learning can provide a bridge between individual and organisational learning (Aslam et al, 2011). Sharing tacit knowledge enables other colleagues to draw on and use it to develop their own practice. The knowledge can then become tacit as it is embedded in the practice of these colleagues who, in turn, can make it explicit to others. This creates the potential for a 'snowball effect' both within an individual as knowledge is shared and learning is developed, and between individuals as knowledge and learning are further developed, shared, and spread through a team and organisation. The implication of this is that projects should be designed and managed to create space for the exploration of practice and understandings that reveal tacit knowledge and enable its transfer. One way of achieving this is to create space for dialogue which is not too tightly focused on technical aspects of project implementation. Where people have the time and space to talk, social relationships are an important means of sharing individuals' knowledge, including the conversion of the tacit to 
the explicit (Janhonen and Johanson, 2011). One of the project participants identified 'time and space' as two of the aspects of the planning of the project they had found most useful. Providing the 'right sort' of space is important, as suggested by one project stakeholder's reference to the value of the residential event: 'The residential was really good - because we were away - able to really focus and talk through issues...'.

Overall, the project had an important impact in bringing people together to focus on a common issue. This is particularly important in the complex context of the workplace where, as Fischer and Nakakoji (1997) have found, much work knowledge is developed and held collectively. The authors' experience is that this is true of their own organisation where colleagues work collaboratively across a range of programmes. Here, not only is knowledge developed and held collectively, but the particularity of each individual's knowledge is increased by the unique work profile they have. In Waibel-Fischer et al.'s (2004) terms, they have 'local knowledge'. This project involved participants who might not otherwise have worked together (as noted by one of the team members), and generated a rich and sustained dialogue, which did not rely on formal team meetings alone. The sharing involved in this dialogue may be seen as representing the 'work process knowledge' which co-ordinates understanding across groups (Waibel-Fischer et al., 2004). Projects may thus be seen as potentially creating knowledge and learning which go beyond the focus of an individual project.

Another way in which projects might encourage a move from individual to organisational learning is that they can support transformational leadership, involving the development of the skills of leading, interpreting and addressing problems, openness to new information, and learning from experience that are associated with organisational change through transformational leadership (Leithwood et al, 1998). Some emphasise the role of leaders in directing learning if it is to become organisational (for example, Mazutis and Slawinski, 2008). Stacey and Griffin (2005), however, highlight the complexity of the process and argue that what happens depends not on the plan of a leader, but on how people respond through their interactions. In this perspective, organisations will only truly become learning organisations when they give power back to those directly involved rather than try and control the process and outcomes of that thinking (Eraut and Hirsh, 2007).

\section{Using the learning from the CABLE project - Identifying and supporting opportunities for individual professional learning and development}

The emphasis of much of the literature on project-based learning is the potential contribution this can make to organisational learning, rather than on the possibilities for individual professional learning and development. This aligns with the team-based approach needed for managing projects and the value of learning together through a shared experience. Indeed, the CABLE project stakeholders' responses to the evaluation suggested that they valued many of the aspects of working with colleagues. They referred, for example, to: making 'professional relationships', building on 'mutual trust and respect', the discussions (not necessarily in formal meetings), team working, opportunities for networking, and 'learning more about colleagues and how they teach and think.' However, the findings from the evaluation also included some reflections on the contribution of the project towards the participants' individual professional learning and development, such as greater understanding and 
confidence. This can be planned for, as experience does not equate to learning. Experience needs to be examined so that learning can emerge from the reorganisation and reconstruction of experience (Dewey 1916/1966), or to be examined to identify events which can be 'critical' to learning.

Drawing on the project stakeholders' reflections, ten questions or suggestions have been identified that could be used to encourage project teams to consider how a project might be used as a source of individual professional learning and development (Table 2). Such opportunities might be considered during the process of planning the project, and reviewed as the project is carried out and evaluated. Furlong and Salisbury (2005) argue, in a study of teachers, that the impact of projects on professional development should be included as one of the criteria considered as part of project evaluation.

\section{Table 2 Questions or suggestions that could be used to identify and support professional learning and development opportunities from projects}

1. Which colleagues are willing to support members of the project team at both strategic and operational levels?

(For example, colleagues with strategic leadership and management experience, 'critical friends', students, and members of professional and technical staff might be willing to provide ongoing support).

2. Could an experienced project leader support and mentor a colleague new to the project leadership role?

3. Could time be spent away from the workplace for planning and team building?

4. Could project team members be supported and encouraged to develop a 'project learning community' and to reveal and share tacit knowledge and learning?

(For example, by providing opportunities for formal and informal dialogue and reflection)

5. Could the project be disseminated at intervals throughout the duration of the project to allow for ongoing feedback?

(Dissemination methods might include posters, plasma screen presentations, professional development sessions and conferences).

6. Are there opportunities for developing professional relationships, partnership working and networking or for using links which have already been developed?

7. Will there be opportunities for further collaborative work, building on partnerships and networks developed during the project?

8. Do members of the project team need to take part in particular professional development activities before the project starts or during the project?

9. Have members of the project team reflected on the professional development activities provided by the project and the ways in which these might be used or supported in the future?

10. How will members of the project team 'capture' and share their learning through the project? 
In relation to management development, Mumford (1991, p. 119) suggests that such a planned approach is not usual, commenting:

'Very rarely are the specific opportunities for particular learning identified in advance, reviewed beforehand with individuals, subsequently reviewed and discussed...

'It is critical that we manage to improve the capacity of individuals to recognise and take advantage of learning opportunities...'

Carter and Halsall (2000), reflecting on a change management project in higher education, refer to the need to consider the professional development requirements of members of staff who lead and manage the project, with a particular focus on change management skills. While this is so, it is unlikely to be sufficient as the complexity of organisations is increasingly evidenced. Complexity theory develops a holistic or ecological perspective rather than a reductionist or atomistic one (Gleick, 1993), which has implications for the perspective of change management that is used, and the particular skills that are developed. More specifically, participants' experiences here might suggest that it is the 'softer' skills and understandings associated with learning through dialogue that are key in maximising the breadth, depth, and visibility of learning and development of individuals and organisations.

Using the findings from the study reported in this article, it is suggested that a prospective, proactive approach might be taken to consider a wider range of professional learning and development opportunities available during a project. For example, a colleague keen to develop their research skills could engage with an experienced researcher to manage the evaluation process. Such considerations might in some cases influence the choice of members of a project team. This would allow project managers to gain additional value from a project, an issue of particular interest when funding is limited. It would also raise awareness of the possibilities for professional learning in everyday work practice including, for example, 'everyday conversation' (Haigh, 2005) or what Senge (1994, p. 18-19) refers to as 'real conversation' or '"learningful" conversations', requiring reflection.

Describing a community of practice as 'a social learning system', Wenger (2010, p. 179, 181) emphasises the individual 'as a social participant, as a meaning-making entity' and asserts that 'Learning is not just acquiring skills and information; it is becoming a certain person - a knower in a context where what it means to know is negotiated with respect to the regime of competence of a community.' Encouraging and supporting team members to build a community of practice (Wenger et al, 2002) or a 'project learning community' might be a mechanism for developing an environment conducive to maximising learning opportunities throughout a project, and for supporting team members as they engage in project-related professional learning and development. Such a community might have a more overt focus on learning than most project teams, and one practical challenge is how members of a group could fulfil both the functions of a 'project team' and those of a 'learning community' without compromising one function or the other. The nature of the challenge was identified by Lindkvist (2005, p. 1190) who explored the relationship between the nature of groups that form a community of practice, as set out in the literature (see for example, Wenger et al, 2002), and project groups, which he suggested operate more as a 'collectivity-of-practice'. In his discourse of the characteristics of each type of group he put forward the notions of the 'knowledge community' and the 'knowledge collectivity', suggesting that whereas in the former individuals learn by socialisation and the knowledge base is 'decentred' and resides in 'Knowledge-as-practice, Communal activity and narratives' in the latter individual members 
learn through solving problems, and knowledge is 'distributed' and resides in 'Individual knowledge and competences' (Lindkvist, 2005, p. 1205). Lindkvist's view has implications for sharing tacit knowledge, discussed earlier, and highlights the complexity of characterising different types of groups, given the uniqueness of the nature, purpose and membership of each one even within a single organisation.

In proposing the model of the 'double-knit' organization McDermott (1999, p. 34) has provided a useful delineation of the differences between teams and communities of practice asserting that they 'are different kinds of groups. Teams are tightly integrated units driven by deliverables, defined by managed tasks and bound together by members' collective commitment to results. [Communities of practice] are loosely knit groups driven by the value they provide to members - defined by the opportunities to learn and share what they discover and bound by the sense of collective identity that the members form.' However, most project teams do have some of the characteristics of a community of practice as proposed by Wenger et al (2002), and of a learning community, defined as '.... s space in which people come together; explore, enquire and exchange views, opinions and knowledge; and learn and grow as a community' (University of Hertfordshire School of Education, 2006). McDermott (1999, p. 34) also suggests that communities of practice are 'based on trust'; one of the features that contribute to the part teams can play in supporting learning (McDermott, 1999, p. 33):

'Teams can be great vehicles for learning because their structures provide the safe environment people need to explore new ideas and challenge their own assumptions. When members develop trust and rapport, they can feel safe enough to share their thinking, the reasons behind their conclusions, the questions they have about their conclusions and even their half-baked ideas. When they take time to collectively reflect on their experience, they can build on each other's ideas and deepen the richness of their thinking and insights.'

As Edwards (2012, p. 26) suggests when discussing the link between communities of practice and professional learning communities, and acknowledging the uniqueness of each community: 'The members create and make meaning from their shared experiences and within their social relationships in this context.' It is this type of community that 'discovers value in many day-to-day exchanges of knowledge and information' (McDermott, 1999, p. 34) that could support the surfacing and sharing of tacit knowledge described above and encourage learning throughout a project.

\section{Conclusion}

The project described in this article is one example of the many funded projects that are a common feature in higher education settings within the UK. Although some lessons from change projects are project specific, others can be shared for learning more widely (Carter and Halsall, 2000). The findings from this evaluation have been used to suggest a means of managing opportunities for individual learning and professional development in future projects; an approach that complements the methods of 'learning from projects' already in use. The questions or suggestions identified within this article are illustrative and can be adapted to suit particular settings.

This approach places an emphasis on the potential for supporting future practice by taking a structured approach to learning through the process of a project. Whereas an unplanned 
approach to learning within a project might restrict both the quality and quantity of learning that takes place (Sense, 2007), team members could be encouraged to identify opportunities for individual professional learning and focus on these as additional and important outcomes of the project. Encouraging the project team to develop as a community of practice or a 'project learning community' might be one mechanism for enhancing the learning that can take place throughout a project.

\section{Acknowledgements}

The authors would like to thank all those who contributed to the CABLE project and to the evaluation process.

\section{References}

Anderson, I., Bullen, P., Alltree, J. \& Thornton, H. (2008) CABLE: an approach to embedding blended learning in the curricula and across the institution, Reflecting Education, 4(1), 30-41. Available online at: http://www.reflectingeducation.net/index.php/reflecting/article/view/53 (Accessed 8 February 2013).

Argote, L. \& Miron-Spektor, E. (2011) Organizational Learning: From Experience to Knowledge, Organization Science, 22(5), 1123-1137.

Argyris, C. \& Schön, D. A. (1978) Organizational learning: a theory of action perspective, (Reading, UK: Addison-Wesley Publishers).

Argyris, C. (1999) On organizational learning, (Malden, MA, Oxford, UK: Blackwell Publishers Ltd), $2^{\text {nd }}$ edn.

Aslam, H. D., Javaid, T., Tanveer, A., Khan, M., \& Shabbir, F. (2011) A Journey from Individual to Organizational Learning. (Exploring the linking bridge: Team Learning), International Journal of Academic Research, 3(3), 738-745.

Ayas, K. (1996) Professional project management: a shift towards learning and a knowledge creating structure, International Journal of Project Management, 14(3), 131-136.

Barker, M. \& Neailey, K. (1999) From individual learning to project team learning and innovation: a structured approach, Journal of Workplace Learning, 11(2), 60-67. Available online at:

www.emeraldinsight.com/Insight/ViewContentServlet?Filename=/published/emeraldfulltexta rticle/pdf/0860110203.pdf (Accessed 8 February 2013).

Bickmore, D. L. (2011) Professional learning experiences and administrator practice: is there a connection?, Professional Development in Education, DOI:10.1080/19415257.2011.579004.

Bloch, D. \& Borges, N. (2002) Organisational Learning in NGOs: An Example of an Intervention Based on the Work of Chris Argyris, Development in Practice, 12 (3/4), 461-72. Available online at: http://www.jstor.org/stable/4029515 (Accessed 8 February 2013).

Boreham, N. C., Samurçay, R. \& Fischer, M. (2002), eds, Work Process Knowledge, (London: Routledge). 
Britton, B. (2002) Learning for Change: Principles and practices of learning organisations, The Swedish Mission Council. Available online at:

http://www.wageningenportals.nl/sites/default/files/resource/learning_for_change__bruce_britton_smc_2002.pdf (Accessed 8 February 2013).

Carter, K. \& Halsall, R. (2000) Development projects as a vehicle for managing change in higher education: learning from the journey, Research in Post-Compulsory Education, 5(3), 317-348.

Chavez-Tafur, J., Hampson, K., Ingevall, A.. \& Thijssen, R. (2007) Learning from experience. A manual for organising, analysing and documenting field based information, ILEIA, Centre for Information on Low External Input and Sustainable Agriculture. Available online at: http://www.agriculturesnetwork.org/library/81067 (Accessed 8 February 2013).

Church Urban Fund (2006) Project Reflection Workshop, (London: Church Urban Fund). Available online at: http://www.cuf.org.uk/sites/default/files/Project\%20Reflection\%20Workshop2.pdf (Accessed 8 February 2013).

Davies, R. \& Dart, J. (2005) The 'Most Significant Change' (MSC) Technique - A Guide to Its Use, Version 1 - April. Available online at: http://www.mande.co.uk/docs/MSCGuide.pdf (Accessed 8 February 2013).

Denton, D. K. (1996) Four simple rules for leading change, Empowerment in Organizations, 4(4), 5-9.

Dewey, J. (1916/1966) Democracy and education. An introduction to the philosophy of education, (New York: The Free Press).

Edwards, F. (2012) Learning communities for curriculum change: key factors in an educational change process in New Zealand, Professional Development in Education, 38(1), 25-47.

Eraut, M. (2004) Informal Learning in the Workplace, Studies in Continuing Education, 26 (2), 247- 273.

Eraut, M. \& Hirsh, W. (2007) The Significance of Workplace Learning for Individuals, Groups and Organisations, Skope. Available online at: http://www.skope.ox.ac.uk/sites/default/files/Monogrpah\%209.pdf. (Accessed 8 February 2013).

Evans, K., Hodkinson, P., Rainbird, H. \& Unwin, L. (2006). Improving workplace learning, (Oxon: Routledge).

Fischer, G. \& Nakakoji, K. (1997) Computational environments supporting creativity in the context of lifelong learning and design, Knowledge Based Systems, 10(1) 21-28

Fischer, M. \& Röben, P. (2002) Organisational learning and knowledge sharing: The use, documentation and dissemination of work process knowledge, Paper for the European Conference on Educational Research (ECER), Lisbon, September 11-14. Available online at: http://www.itb.uni-bremen.de/projekte/orglearn/DownLoad/ECERPaper.pdf (Accessed 8 February 2013).

Fong, P. S. W. (2003). Knowledge creation in multidisciplinary project teams: an empirical study of the processes and their dynamic interrelationships, International Journal of Project Management, 21, 479-486. 
Fullan, M. (1993) Change Forces: probing the depths of educational reform, (London: Falmer Press).

Furlong, J. \& Salisbury, J. (2005) Best Practice Research Scholarships: an evaluation, Research Papers in Education, 20(1), 45-83.

Gleick, J. (1993) Chaos: Making a New Science, (London: Abacus).

Haigh, N. (2005) Everyday conversation as a context for professional learning and development, International Journal for Academic Development, 10(1), 3-16.

Higher Education Academy (2011) [Internet] Change Academy. Available online at: http://www.heacademy.ac.uk/resources/detail/change/change_academy (Accessed 8 February 2013).

Janhonen, M. \& Johanson, J-E. (2011) Role of knowledge conversion and social networks in team performance, International Journal of Information Management, 31(3), 217-225. doi:10.1016/j.ijinfomgt.2010.06.007

Keegan, A. \& Turner, J. R. (2001) Quantity versus Quality in Project-Based Learning Practices, Management Learning, 32(1), 77-98.

Koskinen, K. U., Pihlanto, P. \& Vanharanta, H. (2003) Tacit knowledge acquisition and sharing in a project work context, International Journal of Project Management, 21, 281-290.

Kotnour, T. (2000) Organizational learning practices in the project management environment, International Journal of Quality \& Reliability Management, 17(4/5), 393-406.

Leithwood, K., Leonard, L., \& Sharratt, L. (1998) Conditions fostering organizational learning in schools, Educational Administration Quarterly, 34(2), 243-276.

Levy, R., Dickerson, C. \& Teague, J. (2011) Developing blended learning resources and strategies to support academic reading: a student-centred approach, Journal of Further and Higher Education, 35 (1), 89-106.

Lindkvist, L. (2005) Knowledge Communities and Knowledge Collectivities: A Typology of Knowledge Work in Groups, Journal of Management Studies, 42(6), 1189-1210

Lom, E. \& Sullenger, K. (2011) Informal spaces in collaborations: exploring the edges/boundaries of professional development, Professional Development in Education, 37(1), 55-74. doi:10.1080/19415257.2010.489811.

Mazutis, D. \& Slawinski, N. (2008) Leading organizational learning through authentic dialogue, Management Learning, 39 (4), 437-456.

Mayes, T., Adamson, V. \& Plenderleith, J. (2008) Challenges and Realisations from the Higher Education Academy/JISC Benchmarking and Pathfinder Programme, JISC/HEA Available online at:

http://rscuk.jiscinvolve.org/wp/files/2008/10/bench_and_pathfinalreview200809261.pdf (Accessed 8 February 2013).

McDermott, R. (1999) Learning across teams. How to build communities of practice in team organizations, Knowledge Management Review, 8, 32-36.

Mitchell, J., Riley, P., \& Loughran, J. (2010). Leading professional learning in schools: Emotion in action, Teacher Development, 14(4), 533-547. 
Mumford, A. (1991) Individual and organisational learning: balance in the pursuit of change, Studies in Continuing Education, 13(2), 115-125.

NHS National Library for Health: Specialist Library Knowledge Management (2005) ABC of Knowledge Management, Contributor: Caroline De Brún. Available online at: http://web.idrc.ca/uploads/user-S/11479492851ABC_of_KM.pdf (Accessed 8 February 2013).

Nonaka, I., Umemoto, K. \& Senoo, D. (1996) From Information Processing to Knowledge Creation: A Paradigm Shift in Business Management, Technology in Society, 18(2), 203-218.

Nonaka, I. \& Takeuchi, H. (1995) The Knowledge-Creating Company: How Japanese companies create the dynamics of innovation, (New York: Oxford University Press).

Oswick, C., Anthony, P., Keenoy, T., Mangham, I. L., \& Grant, D. (2000) A dialogic analysis of organizational learning, Journal of Management Studies, 37(6), 887-902.

Roth, G. \& Kleiner, A. (1998) Developing Organizational Memory Through Learning Histories, Organizational Dynamics, Autumn, 43-59.

Saunders, M. (2000) Beginning an Evaluation with RUFDATA: Theorizing a Practical Approach to Evaluation Planning, Evaluation, 6(1), 7-21. Available online at: http://evi.sagepub.com/cgi/content/abstract/6/1/7 (Accessed 8 February 2013).

Schindler, M. \& Eppler, M. J. (2003) Harvesting project knowledge: a review of project learning methods and success factors, International Journal of Project Management, 21, 219228.

Senge, P. M. (1994). Moving forward. In: P. M. Senge, A. Kleiner, C. Roberts, R. Ross, B. Smith (Authors). The Fifth Discipline Fieldbook: Strategies and tools for building a learning organization, (Crown Publishing Group), 15-47.

Senge, P. M. (2006) The Fifth Discipline. The Art and Practice of The Learning Organization, (London: Randon House Business Books).

Sense, A. J. (2007) Structuring the project environment for learning, International Journal of Project Management, 25, 405-412

Sense, A. J. (2009) The social learning character of projects and project teams, International Journal of Knowledge Management Studies, 3(3-4), 195-208.

Stacey, R. \& Griffin, D. (2005) Introduction: researching organizations from a complexity perspective, In Stacey, R. and Griffin, D., eds, A Complexity Perspective on Researching Organisations: Taking experience seriously, (London and New York: Routledge), 1-12.

Stacey, R. D. (2001) Complex responsive processes in organisations: Learning and knowledge creation, (London and New York: Routledge).

University of Hertfordshire School of Education (2006). Learning and teaching. Building learning communities 2006/07, University of Hertfordshire, UK.

Waibel-Fischer, M., Dick, M. \& Wehner, T. (2004) Local knowledge in activity systems: the socio-cultural perspective of knowledge development. In European Perspectives on Learning at Work: The acquisition of work process knowledge, In Fischer, M., Boreham, N. and Nyhan, B., eds, Cedefop Reference Series; 56 Luxembourg: Office for Official Publications of the European Communities, 71-95 
Wenger, E., McDermott, R. \& Snyder, W. (2002) Cultivating communities of practice: a guide to managing knowledge, (Boston: Harvard Business School Press).

Wenger, E. (2010) Communities of practice and social learning systems: the career of a concept, In Blackmore, C., ed, Social Learning Systems and Communities of Practice, (Springer London and the Open University), 179-198. 